\title{
LIABILITY OF CORPORATE SHARES TO LEGAL PROCESS
}

\author{
PierRe R. LoISEAUX*
}

Judgment creditors have a persistent problem of collecting money. In the case of individuals, much of today's wealth is protected by exemption statutes. The residence of a debtor is protected from his creditors by statute or the concept of the common-law estate by the entirety. The homestead is exempt to some extent in all states and completely exempt in a few. ${ }^{1}$ Various personal property exemptions are found in all states, some limited by total dollar amounts and others limited only by the nature of the property. ${ }^{2}$

One type of wealth which is not included in exemption statutes is ownership of shares in a corporation. ${ }^{3}$ Because of the vastness of wealth represented by this type of ownership, it is important that creditors in all states have a uniform method of levying or attaching corporate stock. As was said by Judge Lloyd in a New Jersey case:

Shares of stock are now possibly the most widely prevalent form of title to joint interest in property, and their certificates are to the possessor the evidence of his right. As is commonly known, millions of shares are transferred daily from one owner to another, and in the stock exchanges of the country comprise perhaps the major part of their transactions. On small pieces of paper are written the evidence of fortune. It is therefore of great importance that these titles should rest upon a sure foundation. ${ }^{4}$

Ownership of shares in corporations is represented by pieces of paper called certificates of stock. These certificates may be in the actual possession of the owner, or pledged to a lender, or in a safety

* Professor of Law, University of California at Davis. LL.B. 1950, Boston University; LL.M. 1951, New York University.

1. See generally S. Riesenfeld, Creditors' Remedies and Debtors' Protection 23050 (1967).

2. Exemptions are quite common for clothing, household equipment and furniture, tools of trade, automobiles, insurance, and numerous government benefits, both state and federal. For an excellent discussion of these matters, see Countryman, For a New Exemption Policy in Bankruptcy, 14 RuTGERS L. REv. 678 (1960).

3. The greatest segment of this wealth is represented by ownership in large national corporations. The certificates representing this wealth are traded daily on national exchanges. Another large ownership group is represented by shares which are registered but not listed on national or regional exchanges. These securities are traded on the "over-the-counter" markets. A further group of ownership interests of unknown size are unregistered shares in small corporations which may be owned by a single family or a group of entrepreneurs.

4. Wallach v. Stein, 103 N.J.L. 470, 472, 136 A. 209, 210 (Ct. Err. \& App. 1927). 
deposit box or in innumerable other physical situations. Whatever the physical situs of the certificates of stock, the wealth represented by these certificates should be available to the creditors of the owner. If the piece of paper itself represents the wealth, then the judgment creditor must somehow get possession of the certificate. If, however, the ownership interest is the wealth, then the judgment creditor must utilize a procedure enabling him to collect upon the intangible chose in action. Unfortunately for the judgment creditor, both views of the nature of the wealth represented by ownership of shares in a corporation prevail and have prevailed for many years.

If the piece of paper is the res, what procedures are available to the creditor? Assuming that the debtor has the certificate in his pocket, can the sheriff levy execution upon the paper by removing it from the pocket of the debtor? If the certificate is pledged, what process will reach the certificate or the debtor's interest therein? Is garnishment available against the lender or the broker? Can legal process get the certificate out of a safety deposit box? Does it make any difference if the certificate is in the name of a street address or if the debtor has fraudulently conveyed it to another who is now in possession? Are there other remedies available to the creditor, such as a bill to reach and apply or supplementary proceedings?

If the certificate is not the res, the creditor must then concern himself with the place of incorporation of the issuer of the shares. What procedure must be followed in that place? If the shares may be taken without obtaining possession of the certificate, what is the status of a subsequent bona fide purchaser of those certificates in the ordinary course of business? If a certificate is taken and it does not represent the ownership interest, can it be used to satisfy the judgment?

If a single state or nation persists in creating shares that are not embodied in a certificate, can the creditor safely proceed without first knowing the situs or the de facto situs of the corporation which issued the stock? Will the procedure to be followed by the creditor be determined by whether the ownership interest is a "security" within the meaning of the Uniform Commercial Code? ${ }^{5}$ If the interest sought is not a "security," then what law governs the reaching of that interest and what procedures must the creditor pursue?

This article will attempt to answer most of the questions concern-

5. See Uniform Commercial Code $§$ 8-102(1). 
ing creditors' remedies posed in the above paragraphs. After briefly reviewing the common-law methods by which creditors reached ownership interests in corporations, the discussion will center upon legislative attempts to provide for uniform answers to these questions through the Uniform Stock Transfer Act and the Uniform Commercial Code. However, in some instances, where there is no legislative or judicial solution, this article can only suggest answers to these questions.

\section{Common Law and Pre-USTA Statutes}

At common law the ownership interest in the legal fiction called a corporation was classified as an intangible chose in action and was not subject to legal process. ${ }^{6}$ Thus, the only procedure available to reach ownership interests in corporations was the creditors' bill. ${ }^{7}$ It was also customary in some areas not to issue any certificate evidencing shares of stock in a corporation. When certificates were issued, their existence was not related to the actual ownership of the shares. The corporate books were the sole and controlling evidence of ownership. ${ }^{8}$

The first step leading to the recognition of the certificate of stock as evidence of a corporate ownership interest was the enactment of statutes subjecting the certificate to legal process. This was done in the middle of the nineteenth century by most states. ${ }^{9}$ At the same time, some statutes made the issuance of certificates a requirement for all corporations. ${ }^{10}$ The legal process selected by the legislatures at that time was levy by notice to the corporation. Under this process, the creditor obtained a writ of execution, attachment, or garnishment, and the sheriff made a levy under that writ by leaving a copy

6. At common law ... shares of corporate stock, being intangible and incapable of physical seizure, and not being debts due and collectible from the corporation at the stockholders' will, were not the subject of attachment and levy . . . Elgart v. Mintz, 123 N.J. Eq. 404, 406, 197 A. 747, 749 (Ch. 1938).

7. A creditor's bill is a suit by a judgment creditor in equity for the purpose of reaching property which cannot be reached by levy and sale under an execution at law. See Newman v. Willetts, 52 11l. 98 (1869).

8. See Reynolds v. Reynolds, 54 Cal. 2d 669, 355 P.2d 481, 7 Cal. Rptr. 737 (1960).

9. Law of the 1805 May Session, 689-90, [1805] Conn. Laws (superseded 1848); Law of March 22, 1872, $\$ 52-54$, [1872] 111. Laws (superseded 1894); Law of March 9, 1842, $\$ 5$, [1841-45] N.J. Laws (repealed 1948).

10. Law of May 20,1861, ch. $82, \S 14,[1861]$ Cal. Laws (codified at CAL. Code CIV. Pro. $\$ 541$ (West 1955)); Law of Apri] 29, 1874, P.L. $73 \S 17,[1874]$ Pa. Laws (codified at PENN. Stat. AnN. tit. 15, $\$ 1601$ (Supp. 1972)). 
with one of the principal officers of the corporation. Statutes normally spelled out in some detail which officers were to be served with the process and the proper place for service. The sheriff would then proceed to sell the interest to the highest bidder at public sale. The corporate officer made a certificate of sale to the purchaser who would be issued a new certificate for the appropriate number of shares, and the outstanding certificate in the hands of the judgment debtor was made void and cancelled.

This pre-Uniform Stock Transfer Act period was favorable to creditors, for under the levy by notice system the creditor was certain to obtain the debtor's interest in a corporation, unless the debtor sold or assigned his interest before the creditor served the writ. Problems were encountered, however, when the state of incorporation and the domicile of the debtor were not identical. Under the levy by notice process, the creditor was required to go into another jurisdiction to enforce his judgment and, thereafter, the collection rights. The statutes in this period gave no protection to purchasers and lenders because under the levy by notice process they could not be sure that they were buying a good title in the stock without checking the records of the corporation before making the purchase or loan. As a further complication, the prospective purchaser or lender, not being a stockholder, had no legal right to examine the records of the corporation."

\section{The Uniform Stock Transfer Act}

As the number and value of corporate shares grew, pressure to provide protection for purchasers and lenders became greater. It was not practical in a business sense to make an investigation before purchasing or lending. The enactment of the Uniform Negotiable Instruments Act ${ }^{12}$ did not solve this problem, since corporate shares were ownership interests rather than fixed obligations and thus were not within the definition of negotiable instruments. Action which would enable the purchaser to take a certificate, regular on its face, and be assured of a good title was needed. With this background, the Commissioners on Uniform State Laws decided that the best solution was to give negotiability to the certificate evidencing ownership in the corporation.

11. See Reynolds v. Reynolds, 54 Cal. 2d 669, 355 P.2d 481, 7 Cal. Rptr. 737 (1960).

12. For the text of the Uniform Negotiable Instruments Act, see 5 UNiform LAws ANN. (1922). The Uniform Negotiable Instruments Act was adopted by the Commissioners on Uniform State Laws in 1896 and was subsequently enacted in every jurisdiction. 
Thus, the Commissioners adopted the Uniform Stock Transfer Act (USTA) ${ }^{13}$ in 1909. The USTA gave stock certificates negotiability and included in its coverage "a share or shares of stock in a corporation organized under the laws of this state or of another state whose laws are consistent with this act." ${ }^{14}$ In reference to creditors' remedies, section 13 provided that no attachment or levy should be valid unless: (1) the certificate was actually seized by the officer making the levy or attachment; or (2) the certificate was surrendered to the corporation which had issued it; or (3) the transfer of the certificate by the holder was enjoined. Section 14 provided that the creditor should be entitled to such aid from the courts as was traditionally available in equity to a creditor who sought to reach property not subject to legal process. This proposed uniform act would terminate the existing practice of making levy by notice to the corporation.

Under the USTA it was not necessary in every case to obtain possession of the certificate itself, for section 13 provided that a levy could be made by enjoining the holder from disposing of the certificate. Suppose that the holder of the certificate after service of the injunction nevertheless sold the certificate to a bona fide purchaser in the ordinary course of business. The other provisions of the USTA would lead one to conclude that the purchaser should be protected. ${ }^{15}$ Under that result, the creditor would receive no benefit from the injunctive remedy except a cause of action against a debtor who had already demonstrated an unwillingness to pay his debts.

\section{Modification of the USTA by State Legislatures: Problems of Nonuniformity}

The USTA was adopted in some form by all states during the next thirty years. The Commissioners' idea was sound for, though it made collection more difficult for judgment creditors, it protected the market for purchasers and lenders. The USTA was criticized, however, in providing for the negotiability of certificates and, consequently, requiring an attachment process which would be extremely difficult to apply. ${ }^{16}$ Thus, in about one-half of the states the USTA did not

13. For the text of the Uniform Stock Transfer Act, see 6 Uniform Laws ANn. (1922).
14. Uniform Stock Transfer Act $\S 22$.
15. See id. $\$ 1,4-6,8$. See also Overlook v. Jerome Portiand Copper Mining Co., 29 Ariz.

15. See id. $\$ 1,4-6$,
, 243 P. 400 (1926).

16. Under the Act, no attachment or levy upon the shares is valid unless the certificate itself be seized or surrendered to the corporation or its transfer by the holder be enjoined. While section 14 is designed to empower courts to give necessary aid in 
survive its passage through the legislatures in the proposed form.

California did not pass the USTA for many years after it was proposed, and when it was enacted, the first sentence of section 13 was omitted, ${ }^{17}$ thereby partially retaining the pre-existing system of levy by notice to a corporate officer. The problems that arose as a result of California's failure to enact section 13 in the form recommended by the Commissioners are illustrated in Reynolds $v$. Reynolds. ${ }^{18} \mathrm{~A}$ divorce decree granted the wife ownership of a specified number of corporate shares, the certificate for which was in the possession of the husband, who was not a resident of California. The wife brought an action to declare that the stock was hers, and the court so decreed. Subsequently, the wife brought an action against the corporation to compel it to issue to her a certificate for the number of shares of which she had been adjudged the owner. The California Supreme Court held that the corporation could not be ordered to issue the certificate under the express terms of the USTA (as enacted by California) because the original certificate was not surrendered; however, the wife did own the stock, and it would be proper for the lower court to order the corporation to pay dividends to her and to permit her to vote the shares. This "split" ownership, a result compelled by the failure to enact section 13 as proposed, was highly unsatisfactory.

Other states omitted section 13 entirely, and some amended it to conform to existing practice in the area of creditors' remedies. ${ }^{10}$ Some states retained the process of levy by giving notice to the corporation, even though they gave recognition to negotiability of corporate stock certificates in other respects. Some states actually adopted a dual system whereby an individual could either seize the certificate or give notice to the corporation. ${ }^{20}$ About half of the states adopted sections

reaching the certificate, it goes without saying that an attaching process requiring a creditor to go this far and not allowing him to stop with the corporate books will be extremely difficult of application, and, it may be, so impractical as to remove this class of property from a ercditor's reach entirely. But such a rule is quite consistent with what the act aims to accomplish-negotiability, so far as title is concerned, of the certificate representing the shares, without the limitations involved in compulsory refcrence to company books. Negotiability of this sort cannot easily exist side by side with the present local attaching process. Seymour, The Proposed Uniform Stock Transfer Act, 9 CAL. L. REv. 186, 199 (1921).

17. See Cal. Corp. CODE $§ 2477$ (West 1955).

18. 54 Cal. 2d 669, 355 P.2d 481, 7 Cal. Rptr. 737 (1960).

19. See Note, Levy and Attachment of Corporate Stock, 10 U. FLA. L. REv. 209 (1957).

20. Law of June 30, 1947, ch. 186, § 13, [19471 Kan. Laws (repealed 1965); Law of Aug. $5,1943, \S 13,495$, [1943] Mo. Laws (repealed 1963, effective 1965); Law of Feb. 27, 1943, ch. 
13 and 14 as they were recommended, thus requiring seizure of the certificate or an injunction against transfer by the holder of the certificate. ${ }^{21}$

The cases that followed clearly demonstrated the need for uniformity in this area. If a state enacted the USTA, thus making the certificate negotiable, the certificate could be seized in any jurisdiction, and the creditor would thereby have attached the res as defined by the state of incorporation. Problems for the creditor might still exist, however, since the foreign jurisdiction in which he seized the certificate might have procedural devices designed to attach the ownership interest only by notice to the corporation. Conversely, in a state which did not pass the USTA, thus retaining levy by notice, a creditor might follow the appropriate procedure and sell the interest of the debtor. The purchaser could not require the corporation to issue a new certificate, however, because the original certificate was out of the jurisdiction. This resulted from the fact that although the levy by seizure section of the USTA had not been adopted, the negotiability sections were adopted. Consequently, the corporation could not be compelled to issue new certificates without surrender of the old certificates. ${ }^{22}$ On the other hand, the creditor who successfully seizcd a ccrtificate in a state which had enacted the USTA without

$115, \S 13,[1943]$ Mont. Laws (repealed 1963); MoNt. REv. Codes ANN. § 93-4307(4), 93-5810 (1947); Law of April 26, 1947, § 97, 118, [1947] Okla. Laws (repealed 1961); VT. STAT. ANN. tit. $11, \S 274$ (1959).

21. Law of July $22,1931, \S 13,483,[1940]$ Ala. Laws (repealed 1965); Law of June 13, 1943, ch. 56, § 15, [1943] Ariz. Laws (repealed 1968); Law of May 16, 1917, ch. 325, § 13, [1917] Conn. Laws (repealed 1959); Law of Dec. 23, 1944, ch. 729, § 13, [1944] 58 Stat. 930 (repealed 1963): Law of June 28, 1917, Uniform Stock Transfer Act § 13, [1917] III. Laws (repealed 1962); Law of Feb. 26, 1923, ch. 24, § 13, [1923] Ind. Laws (repealed 1963); Law of March 20, 1944, ch. 12, § 13, [1944] Ky. Laws (repealed 1958); La. Rev. Stat. ANN. tit. 12, $\$ 636$ (1969); Law of July 1, 1910, ch. 73, $\S 37 \mathrm{~m}, 70$, [1910] Md. Laws (repealed 1963); Law of April 22, 1913, § 13, 106, [1913] Mich. Laws (repealed 1964); Law of April 20, 1933, ch. $331, \S 13$, [1933] Minn. Laws (repealed 1966); Law of March 22, 1945, ch. 188, $\S 13$, [1945] Nev. Laws (repealed 1967); Law of 1916 Session, ch. 191, § 13, 398, [1916] N.J. Laws (repealed 1963): Law of May 17, 1913, ch. 600, § 174, [1913] N.Y. Laws (repealed 1964); Law of March 9, 1935, ch. 239, § 13, [1935] Ore. Laws (repealed 1963); PA. STAT. ANN. tit. 12A, § 8-317 (1970): Law of Feb. 9, 1921, ch. 159, § 13, [1921] S.D. Laws (repealed 1967); Law of April 11,1925 , ch. 91, $\$ 13$, [1925] Tenn. Laws (repealed 1964); Law of June 1, 1943, ch. 397, § 13, [1943] Tex. Laws (repealed 1961); Law of July 1, 1927, ch. 55, § 13, [1927] Utah Laws (repealed 1966); Law of March 30, 1956, ch. 428, § 13.1-413, [1956] Va. Laws (repealed 1966); Law of April 18, 1923, ch. 53, § 20, [1923] W. Va. Laws (repealed 1964); Law of Oct. 20, 1939, ch. 513, \& 36, [1939] Wis. Laws (repealed 1965).

22. See Reynolds v. Reynolds, 54 Cal. 2d 669, 355 P.2d 481, 7 Cal. Rptr. 737 (1960); cf. Rony v. Yucca Water Co., 220 Cal. App. 2d 613, 33 Cal. Rptr. 873 (1963). 
any modification would have accomplished nothing if the corporation issuing the stock certificate were incorporated in a state that retained the concept of the share, rather than the certificate, as the ownership interest. ${ }^{23}$ Likewise, an attempt to secure the shares by notice to the corporation in a state that had adopted the uniform version of section 13 was ineffective. ${ }^{24}$ Further problems arose when the court had jurisdiction over the person of the debtor, but not the certificate or the corporation..$^{25}$ If the creditor and debtor resided in a state which had adopted the USTA without modification, but the state of incorporation of the issuer of the debtor's stock was a notice state, the creditor could not get jurisdiction over the shares in his and the debtor's state.

\section{Procedures Under the USTA for Seizure of the Certificate}

The creditors in states which enacted the USTA as recommended had to determine the proper procedure under the USTA for obtaining the certificate itself. In Illinois, it was held proper to seek an injunction against the holder and to follow the injunction with an execution sale. ${ }^{26}$ The purchaser became entitled to a conveyance of the certificate from the holder or a contempt citation against him for failure so to transfer. On the other hand, it was held proper in Pennsylvania to enjoin the corporation, holder, and judgment debtor from transferring the certificate and then to apply for an order of sale. ${ }^{27}$ A subsequent Pennsylvania decision held that for this procedure to be proper it was not necessary to issue an execution first to demonstrate that the certificate could not be seized. ${ }^{28}$

When the certificate is pledged to a lender or held by a broker in a margin account, is there a proper procedure enabling the judgment creditor to reach the debtor's interest? No remedy by garnishment is available because corporate shares are not capable of seizure and sale under the process of garnishment. ${ }^{29}$ The proper procedure under such

23. See United States v. Fidelity \& Deposit Co., 244 F. Supp. 19 (W.D. Mo. 1965); cf. Wirt Franklin Petroleum Corp. v. Gruen, 139 F.2d 659 (5th Cir. 1944) (de facto domicile not in state of incorporation).

24. See, e.g., Claude Neon, Inc. v. Birrell, 177 F. Supp. 706 (S.D.N.Y. 1959); Westerman v. Gilbert, 119 F. Supp. 335 (D.R.I. 1953).

25. See Nederlandsche Handel-Maatschappij, N.V. v. Sentry Corp., 163 F. Supp. 800 (E.D. Pa. 1958).

26. Trade Bond \& Mortgage Co. v. Schwartz, 303 Ill. App. 165, 24 N.E.2d 892 (1940).

27. Henson \& Co. v. Stetser, $26 \mathrm{~Pa}$. Dist. 155 (C.P. 1917).

28. Bell v. Feeney, 41 Pa. D. \& C. 486 (C.P. 1941).

29. An attempted garnishment against a lender who admittedly had excess collateral for payment of a note was dismissed by the Massachusetts Supreme Court. Jordan v. Lavin, 319 
circumstances is a bill to reach and apply. Under this bill, the debtor is ordered to pay the judgment, and upon failure to do so, his shares are sold by a special master. This is a proper proceeding whether or not the creditor has demonstrated that the debtor has possession of the shares; furthermore, this procedure does not conflict with the terms of the USTA. ${ }^{30}$ Does the service of a writ of garnishment constitute an injunction against transfer by the garnishee so as to be within the third method for a valid attachment in section 13 of the USTA? The answer should be "yes," because the writ tells the garnishee not to dispose of any property of the judgment debtor until further order of the court. ${ }^{31}$ However, since the creditor is seeking the debtor's equity and not the pledged certificates, the better view is that garnishment of a pledgee does not come within the terms of the USTA. ${ }^{32}$ Thus, a notice levy against a broker should be valid even in a state that has enacted the USTA.

The Pennsylvania Supreme Court has indicated that if the certificate of stock is in a safety deposit box belonging to the debtor, it is possible to execute upon the contents of the box by serving the bank with the writ of execution..$^{33}$ However, a Pennsylvania statute ${ }^{34}$ specifically refers to a bailee as subject to the writ of execution although the corresponding statute ${ }^{35}$ on attachment garnishment does not so provide. ${ }^{36}$ Hodes $v$. Hodes, ${ }^{37}$ an Oregon case, presents a

Mass. 362, 66 N.E.2d 41 (1946). Cf. Pierce, Wulbern, Murphey Corp. v. Riverside Bank, 203 So. 2d 177 (Fla. Ct. App. 1967).

30. See Central Mortgage Co. v. Buff, 278 Mass. 233, 179 N.E. 628 (1932). But see Frost v. Davis, 288 F.2d 497 (5th Cir. 1961) (this case can be distinguished because the garnishee was probably not the holder).

31. See Cal. Civ. Pro. Code $\$ 540$ (West 1954); N.Y. Civ. Prac. $\$ 6214$ (McKinney 1963); Ill. AnN. Stat. ch. 11, § 21 (Smith-Hurd 1963); Tex. Civ. Stat. art. 4084 (Vernon 1966).

32. See Tryon v. Silverstein, 10 Ariz. App. 25, 455 P.2d 474 (1969).

The levy . . . was not on the stock certificates, but on Sherwood's equity in his account with the plaintiff. The plaintiff held the stock as security for Sherwood's debt to it. As a pledgee it had the right, despite service of the sequestration order, to possession of the certificates and was not under compulsion to surrender them to the sheriff. Hornblower \& IVeeks v. Sherwood, 124 N.Y.S.2d 322, 327 (Sup. Ct.), affd, 282 App. Div. 931, 125 N.Y.S.2d 647, stay granted mem. 306 N.Y. 672, 116 N.E.2d 500 (1953), affd, 307 N.Y. 204, 120 N.E.2d 790 (1954); quoted with approval in Gilman v. Sandow, 29 Misc. 2d 1078, 220 N.Y.S.2d 644 (196I).

33. Williams v. Ricca, 324 Pa. 33, 187 A. 722 (1936). See also Moore, Enforcement of Judgments Against Personalty in the Custody of Third Parties, 1951 U. ILL. L.F. 56, 65.

34. PA. Stat. AnN. tit. 12, § 2115 (1967).

35. Id. $\S 2265$, suspended in part by id., PA. R. CIv. P. $\$ 3241,49$ (1967).

36. $324 \mathrm{~Pa}$. at $37-39,187 \mathrm{~A}$. at 724-25.

37. 176 Ore. 102,155 P.2d 564 (1945). 
somewhat different situation. In Hodes, the court had personal jurisdiction over the debtor, who resided in Oregon; the certificates, however, were in a Washington safety deposit box. The lower court entered an order requiring the debtor to deliver the certificates to the sheriff within five days for the purpose of sale. On appeal the Oregon Supreme Court affirmed and noted that the order did not require the judgment debtor to go to Washington to procure the certificates of stock and then deliver them to the sheriff in Oregon, for the judgment debtor could procure these certificates without leaving Oregon. ${ }^{38}$ The court added that if the debtor did not supply the certificates as ordered, the lower court would have jurisdiction under section 14 of the USTA to appoint a receiver and require the judgment debtor to transfer the certificates to such receiver, or to execute any other document necessary to enable the receiver to obtain the certificates.

When the certificate is in the debtor's possession, it is proper for the creditor to enjoin transfer by the debtor without prior resort to an execution. The creditor may also enjoin the issuing corporation from transferring the certificate. Although the relevant clause in section 13 refers only to "transfer by the holder," the provision does not specifically preclude enjoining other parties. ${ }^{39}$ The most probable reason that an execution is not required prior to the issuance of an injunction against the holder of the certificate is that under an execution in the civil process of levy the sheriff has no authority to seize the certificate from the debtor against his will.

If the judgment debtor has fraudulently conveyed the stock to another individual, the creditor can obtain relief under a creditor's bill or supplementary proceedings. In Rioux v. Cronin, ${ }^{40}$ a Massachusetts case, certain stock was held by the wife of the debtor. The creditor brought a creditor's bill and secured an injunction against transfer by the holder. In an action brought after the death of the judgment debtor, the court held that under section 13 of the USTA there was an effective levy and, consequently, the lien of a creditor's bill survived the death of the debtor. Similarly, a judgment creditor in Pennsylvania enjoined transfer by the debtor and the issuing corporation and, in addition, secured an order that the debtor execute an assignment to the sheriff of his rights in certain additional shares

38. Id. at 116,155 P.2d at 570 (1945). But see Nederlandsche Handel-Maatschappij, N.V. v. Sentry Corp., 163 F. Supp. 800 (E.D. Pa. 1958).

39. Jaski v. Leider, 34 Pa. D. \& C. 480, 484-85 (C.P. 1939).

40. 222 Mass. 131, 109 N.E. 898 (1915). 
which were found to be property of the judgment debtor but which stood in the names of others. ${ }^{41}$ In New York, supplemental proceedings were available to secure a turn-over order against the nominal holders of certificates which were found to be the property of the debtor. ${ }^{42}$

\section{An Evaluation of the USTA}

The USTA was excellent in conception. Had it in fact remained a uniform act after adoption, it would have eliminated most of the problems of creditors, purchasers, and lenders. Unfortunately, the lack of adoption in the recommended form resulted in problems of conflicts and jurisdiction for creditors and insecurity about the title of certificates for purchasers and lenders. But even if the USTA had been uniform in fact, the third alternative of section 13, which allowed an effective levy by service of an injunction on the holders, increased the possibilities of litigation as a consequence of sales made in contempt of court. Lack of litigation reaching appellate courts indicated, however, that it was rare for a holder to successfully transfer in contempt of the court order, ${ }^{43}$ consequently, had the statute been uniform in fact, it would have accomplished at inception its goal to protect both purchasers and creditors. With half a century of experience under the USTA, the Commissioners were well prepared to understand and correct the problems of the USTA when they assembled to draft Article 8 of the Uniform Commercial Code.

Article 8 of the UNiform Commercial Code

Article 8 of the Uniform Commercial Code (UCC) was designed

41. See Tong Y. Chin v. Chin Wing Teung, 34 Pa. D. \& C. 4 (C.P. 1938).

42. See First Small Business Invest. Corp. v. Zaretsky, 52 Misc. 2d 375, 275 N.Y.S.2d 960 (Sup. Ct. 1966), rev'd, 28 App. Div. 874, 282 N.Y.S.2d 973 (1967) (debtor's ownership not shown). Cf. Ballin v. Ballin, 138 N.Y.S.2d 556 (Sup. Ct. 1954) (cannot reach certificate in hands of third party by levy without seizure or injunction).

A case decided by the Illinois Court of Appeals under the USTA concluded that the filing of a creditor's bill constituted an injunction within the meaning of section 13:

While ordinarily plaintiffs do act promptly to sequester "discovered" assets and while the plaintiff herein might have resorted to the interlocutory remedies of injunction or receivership to prevent the transfer and delivery of the certificate of stock by the bank to Wilcox, in our opinion she was under no obligation to do so. Pritchard v. Wilcox, 314 Ill. App. 132, 137, 40 N.E.2d 831, 833 (1942).

When the bank admitted possession of defendant's property, that property came within the court's jurisdiction and the bank could not thereafter change the situation without permission of the court.

43. Cf. Overlook v. Jerome Portland Copper Mining Co., 29 Ariz. 560, 243 P. 400 (1926). 
to replace the USTA, to improve upon it, and, hopefully, to make the law in fact uniform with regard to creditors' remedies. Section 8-317 is based upon sections 13 and 14 of the USTA but is not identical. It will be recalled that under section 13 of the USTA there were three ways in which to make a valid levy: actual seizure of the certificate; service upon the corporation when the certificate had been surrendered to the corporation; and an injunction against the holder of the certificate. Section 8-317(1) clearly reiterates the first two procedures in providing for the methods of valid levy under the Code, but the third alternative is omitted. It is apparent that the drafters of the Code intended to avoid the problems arising from the prior law which permitted a valid levy by enjoining the holder from transfer of the certificate. While the injunction procedure is referred to in section $8-317(2)$ as one of the means whereby the creditor can secure the assistance of a court of appropriate jurisdiction, the issuance of an injunction does not of itself constitute a levy. The creditor can secure the certificate without seizure only if the certificate has been surrendered to the issuing corporation..$^{44}$ Since valid levy can be made only by actual seizure or surrender of the certificate to the issuing corporation, Article 8 also protects the purchaser or lender who extends money or credit on the face of the certificate itself in the ordinary course of business.

\section{Interpretations of Section 8-317}

The few reported cases under section 8-317 indicate that the courts will read the section literally. In Neifeld $v$. Steinberg, ${ }^{45}$ a sheriff attempted to attach certain stock held by a broker in Philadelphia. In the original proceeding the sheriff did not seize the certificate, but simply served notice upon the broker. A subsequent writ of foreign attachment was issued, however, and the sheriff did take possession of the certificate. In holding that the first abortive attempt to secure the certificate was not res judicata upon the subsequent levy, the Third Circuit stated:

The reason why [UCC] $\S 8-317$ requires a party to manually seize securities

\footnotetext{
44. Comment 1 under section 8-317 of the Code expressly makes this point referring to Hodes v. Hodes, 176 Ore. 102, 155 P.2d 564 (1945), as an example of the proper procedure to reach the certificate under section 8-317(2), see notes 38-39 supra and accompanying text, but notes that the procedure is not operative as an effective levy. In the Hodes situation, there could be no levy under section 8-317 until the sheriff actually acquired physical posscssion of the certificate.
}

45. 438 F.2d 423 (3d Cir. 1971). 
in order to effect a valid attachment is to foreclose all possibility of the security finding its way into a transferee's hands after an attempted attachment has been made. This policy has already been vindicated for we take judicial notice that the sheriff manually seized the securities . . . .

Two earlier Pennsylvania cases had made it clear that under the UCC nothing less than actual seizure would be sufficient to effectuate a valid levy. ${ }^{47}$

\section{Enactment of Article 8 by the State Legislatures}

Assuming that the UCC will be construed in substantially the same way by different courts, creditors' rights in domestic stocks would be well protected if all of the jurisdictions had enacted Article 8 of the UCC, without amending the provisions discussed herein. At the present writing all states except Louisiana have enacted the $\mathrm{UCC}^{48}$ and only two states, California and Delaware, have amended section $8-317.49$ The modifications by Delaware are of particular im-

46. Id. at 432 .

47. DeShong v. Cody, 36 Pa. D. \& C.2d 109 (C.P. 1964); Ellison v. Mitchell, 26 Pa. D. \& C. $2 \mathrm{~d} 45$ (C.P. 1961). In both cases, the sheriff served garnishment upon a third party having possession of the certificate, but in neither case did the sheriff obtain possession of the certificate. In each instance the court held that the attempted levy was ineffective under the Uniform Commercial Code.

A sheriff probably cannot take possession of a certificate of stock under the garnishment statutes, since most of the procedures simply instruct the garnishee, after service of the writ, to file an answer at a given time stating what property or credits of the debtor the garnishee holds. Such provisions would need a substantial judicial gloss to be construed to permit the sheriff to seize property in the hands of the garnishee. Cf. Frost v. Davis, 288 F.2d 497 (5th Cir. 1961). This does not mean, however, that certificates of stock are not available to creditors when they are in the hands of third parties. Section 8-3I7(2) suggests that in those cases where it is not possible to obtain seizure of the certificate, other traditional remedies, including the injunction, are to be given by the court. An example of an unsuccessful use of the proper procedure is the recent New York case of Art-Camera-Pix, Inc. v. Cinecom Corp., 64 Misc. $2 d 764,315$ N.Y.S.2d 991 (Sup. Ct. 1970). In that case the judgment creditor restrained the corporation, which had issued warrants to purchase stock; it also served garnishment upon the corporation and commenced supplemental proceedings against both the judgment debtor and the corporation. The court found that the procedure was proper but that the creditor's action must fail because the rights in the stock warrants had been assigned by the debtor before the date of the judgment creditor's action.

48. Louisiana enacted the USTA in 1910, with section 13 in the uniform version as recommended by the Commissioners. LA. REv. STAT. ANN. 12:636 (1969). Under that statute the certificate is the tangible representative of the shares, and it may be taken by legal process in other states under the forum state's code and rules of civil procedure. Therefore, it makes little difference to creditors in other states that Louisiana did not enact the UCC provisions in reference to corporate stock.

49. California added to section 8-317(1) the following: "in the case of a security held in escrow pursuant to the provisions of the Corporate Securities Law, a copy of the writ and a notice that the securities are attached or levied upon in pursuance of such writ is served upon 
portance since many businesses are incorporated in Delaware as a result of the historical development of the law of incorporation. The list of businesses incorporated in Delaware includes large corporations which have no other substantial connection with Delaware. The stock certificates of these corporations are found in all areas of the United States.

Unfortunately for creditors, the Delaware legislature elected not to enact any part of section 8-317(1). In addition, Delaware provided that the adoption of Article 8 shall not repeal, amend, or in any way change the existing Delaware law with respect to levy and attachment of corporate stock. ${ }^{50}$ Since Delaware has enacted without any modifi-

the escrow holder. . . C CAL. Comm. CODE $\S 8-317$ (b)(1) (West 1964). This variation will not create problems similar to those arising from the lack of uniformity in the enactment of the USTA, because this variation applies only to securities which are no longer in circulation.

Thus, no danger of a subsequent bona fide purchaser or lender exists.

50. The Delaware version reads:

Nothing contained in this title shall repeal, amend or in any way effect the provisions of sections 169 and 324 , title 8 , or sections 365 and 366 , and chapter 35 , title 10; and to the extent that any provision of this title is inconsistent with such sections, sections 169 and 324 , title 8 , and 365 and 366 and chapter 35 , title 10 , shall be controlling. DEL. CODE ANN. tit. 5A, $\$ 8317$, Comment (West 1970).

Section 169 , referred to in section $8-317(1)$, provides that for all purposes of title, aetion, attachment, garnishment and jurisdiction of all courts held in Delaware, the situs of the ownership of the capital stock of all corporations existing under the laws of Delaware shall be regarded as in Delaware. Id. tit. 8, \& 169 (Supp. 1968). Section 324 provides that corporate shares may be attached and sold under legal process and that the purchaser at the sale under legal process takes as good a title as the debtor had to such shares. Id. $\$ 324$. Sections 365 and 366 provide for service by publication upon a non-resident, id. tit. 10, $\$ 365-66$, and chapter 35 is the chapter on attachments. Id. ch. 35 . The Delaware Study Comment indieates that the specific references to sections in the Delaware version of this UCC section were inserted to assure that the existing law would not be changed by enactment of the Code. See Note, Attachment of Corporate Stock: The Conflicting Approaches of Delaware and the Uniform Stock Transfer Act. 73 HaRv. L. Rev. 1579 (1960).

The Permanent Editorial Board for the Uniform Commercial Code rejeeted the Delaware amendment, giving the following reasons:

The amendment in this case has the effect of permitting attachment of shares of stock of Delaware corporations and the sale of those shares without the obtaining of possession of the certificates and without any personal service on the registered owner of the shares, even in the case of non-resident owners ... . These provisions are fundamentally contrary to the entire rationale of Article 8 and particularly Section 8-317 which, as a matter of basic policy, base rights of ownership and attachment in major part upon the certificates. Since shares of a Delaware corporation may be attached and sold without physical possession of or any reference to certificates representing the shares, the Delaware provisions can only have the effect of substantially destroying the value of certificates as evidence of ownership and other rights. Delaware has established a position as an appropriate state in which to incorporate and, presumably, desires to retain for itself substantially exclusive jurisdiction as to ownership and control of shares in Delaware corporations. This is its privilege. However, if by the same policy certificates for shares 
cations the remaining parts of Article 8, the effect of the legislation is to protect purchasers and lenders, regardless of where they purchase or lend. The certificate of stock in a Delaware corporation is a negotiable instrument by statute, ${ }^{\mathbf{5 1}}$ and the purchaser or lender takes free of ordinary defenses so long as he meets the tests of Article 8. But can a creditor whose debtor owns shares in a Delaware corporation seize the certificate by legal process in New York or Pennsylvania and thereafter cause the certificate to be sold in satisfaction of his debt? The Delaware statute states that in the event of an attempt to seize corporate shares by legal process the situs of the shares is Delaware. ${ }^{52}$ Therefore, the court in New York or Pennsylvania would not have jurisdiction over the subject matter of the suit. It seems strange that Delaware can create shares which can travel under the certificate for most purposes, but if a creditor levies upon that certificate, then the situs of the shares reverts to Delaware. What Delaware has done is to require that all creditors who would realize upon shares in a Delaware corporation owned by their debtor come to Delaware to litigate. One might also conclude that the bar and the legislature of Delaware were not worried about that "veritable flood of litigation" which has concerned so many judges!

\section{Coverage of Corporate Stock by Article 8}

Upon enacting the USTA, most states repealed earlier statutes subjecting corporate shares to legal process. When the states enacted the UCC, it was recommended that they repeal the USTA. ${ }^{53}$ Thus, the question arises as to what corporate stocks are covered by Article 8. This question is important, for if there are stocks not covered by Article 8 and a state has repealed the USTA, then one must determine what law would govern the levy and sale of such stock.

Most of the pre-USTA statutes in the various states applied to shares in a domestic or foreign corporation. Section 22 of the USTA

of stock of Delaware corporations are vulnerable to attachment and complete transfer of ownership entirely apart from the certificate and without the knowledge of the holder of any certificate, disadvantages to the policy substantially outweigh any benefits. This is certainly true in the case of purchasers or holders of certificates and would seem to be equally true in the case of Delaware corporations and the state of Delaware itself. In addition to the destruction of the uniformity otherwise provided by Article 8, the Board considers the Delaware amendment to be highly unsound in policy. COMMission on Uniform State Laws, Report of Permanent Editorial Board 104 (1966).

51. DeL. CODE ANN. tit. 5A, § 8-105(1) (1971).

52. Id. tit. $8, \S 169$.

53. UNIFORM COMMERCIAL CODE $\S 10-102(1)$. 
defines shares as "stock in a corporation organized under the laws of this state or of another state whose laws are consistent with this act." ${ }^{54}$ The drafters of Article 8 of the UCC were concerned that any definition might exclude types of securities that either were in existence or which might develop in the future, and they did not want to freeze the definition so far as new types of securities were concerned.$^{55}$ For this reason they decided upon a functional definition which brings under the provisions of Article 8 any security, regardless of its name, which meets certain tests. A security which is included in the provisions of Article 8 is functionally defined in section 8-102(1) as follows:

In this division unless the context otherwise requires (a) a "security" is an instrument which (i) is issued in bearer or registered form; and (ii) is of a type commonly dealt in upon securities exchanges or markets or commonly recognized in any area in which it is issued or dealt in as a medium for investment; and (iii) is either one of a class or series or by its terms is divisible into a class or series of instruments; and (iv) cvidences a share, participation or other interest in property or in an enterprise or evidences an obligation of the issuer. ${ }^{56}$

This definition does not expressly refer to corporate stock, but it is apparent that if any issue of corporate stock meets the four tests it will be a "security" within the meaning of Article 8 and will be governed in turn by section 8-317. There is no doubt that stocks listed upon any exchange are included within the term "security." Likewise, any registered stock traded in an over-the-counter market, whether it is national or city-wide, would clearly be included within the definition. ${ }^{57}$ There is considerable disagreement, however, over the question of whether the definition includes all corporate stock. One commentator has suggested that the definition may not be all inclusive in relation to stock:58 Although section 8-102(1) defines "security" for the purpose of applicability of Article 8 broadly enough to include both stocks and bonds, the definition is limited to stock "commonly dealt in upon securities exchanges or markets or commonly recog-

54. UNIFORM Stock TRANSFer ACt $\S 22$.

55. See Uniform Commercial Code \& 8-102, Comment 1.

56. Id. § 8-102(1).

57. The official comment to section 8-102(1) states:

The definition of "security" is functional rather than formal, and it is helieved will cover anything which securities markets, including not only the organized exchanges but as well the "over-the-counter" markets, are likely to regard as suitable for trading. Id. § 8102(1), Comment 1.

58. Rosenthal, Remedies in Disputes Arising Out of Agreements to Buy and Sell Bustnesses, 12 B.C. IND. \& COM. L. Rev. 825, 826 n.4 (1971). 
nized in any area in which it is issued or dealt in as a medium for investment . . . ."59 Consequently, stock in a closely held corporation may not come within the Article 8 definition. ${ }^{60}$ On the other hand, it has been suggested that "Article 8 will apply to a very broad spectrum of instruments, given that the instrument is issued 'in bearer or registered form' and otherwise complies with the broad functional definition stated in section 8-102. It will apply to the stock of even the smallest family corporation . . . ." Another commentator has concluded that:

A security meets the requirement if it is "of a type commonly dealt in" on the organized markets. This does not mean that the particular security must in fact be listed on a stock exchange or traded on a market. Indeed, because of transfer restrictions, it may never leave the hands of the original owners, as in a closely held corporation. Despite the fact that the security may be surrounded by transfer restrictions and purchase options, a close corporation common stock . . . is nonetheless "of a type" which could be traded should the corporation elect to "go public." Thus, the test is whether the security could be publicly traded, not whether it is . . . ${ }^{62}$

What did the drafters of the section mean when they used "of a type commonly dealt in"? This commentator clearly suggests that the phrase includes all corporate stock of a kind that could "go public" whether or not this ever happens or was ever contemplated.

These varying interpretations of section 8-102(1) illustrate that a legitimate question exists as to whether all corporate stock is included within the definition of "security" as used in Article 8, and that the answer to this question must be determined by interpreting the meaning of the phrase "of a type commonly dealt in." If the phrase means "all stock" because all stock could be "dealt in" if certain require-

59. UNiform COMmercial CODE § 8-I02(I).

60 . Rosenthal, supra note 58 , at 826 n.4. Another writer suggests that stock memberships in a nonproprietary golf club, although held to be securities for regulatory purposes, would not comc within the definition of "security" for the purposes of Article 8. J. Smith, 2 California Commercial Law $§ 13.5$ (1965).

61. Huck \& McCartin, The Illinois Uniform Commercial Code: Some Observations and Comments on Article 8-Investment Securities, 50 ILL. B.J. 406, 407 (1962). The commentators also notc that the use of the word "investment" in the title to Article 8 does not prevent the Article from applying to stock in a close corporation. Id. But this analysis is not really addressed to the definition of a "security" given in section 8-102(1) of the Code.

62. Folk, Some Problems Under Article 8 of the Uniform Commercial Code, 5 ARIz. L. REv. 193, 200-0I (1964). Other writers have discussed the definition of "security" but have generally concentrated upon the inclusion of new types of securities, and not upon any possible exclusion of corporate stock. See Israels, Investment Security Problems-Article 8 of the UCC, 11 How. L.J. 120 (1965); Wyatt, Investment Securities-Article 8 of the Uniform Commercial Code, 48 KY. L.J. 333 (1960). 
ments were met, then the question is of no consequence. However, if "commonly dealt in" refers to corporate stock which is of a kind and status to be presently "dealt in," then a substantial number of unregistered stocks would not meet the functional test of the section.

Would it be in the interest of any party to argue that a particular corporate stock was not included within the definition of Article 8? Certainly purchasers and lenders want the protections of the statute and would not be likely to raise the issue. But what about a judgment creditor who is seeking satisfaction of his judgment? If such a creditor were to succeed in convincing a court that the particular stock was not of a type "commonly dealt in," then it would follow that section 8-317 would not apply to his case because that section speaks only of a "security" as defined in the UCC. If the argument were to advance to that point, the court would be faced with the question of what law applies to an interest in a corporation represented by a certificate which was not a "security." If prior statutes were repealed by the enactment of each subsequent statute, then the common law would apply to the case. If common law were applied, the probable rule would be that legal process does not reach such an intangible chose in action, but the interest can be reached in equity with or without the physical presence of the certificate. On the other hand, if the earlier statutes had not been specifically repealed, the creditor might be able to reach the interest by a simple notice to the corporation issuing the stock, or he might be able to enjoin the holder under the USTA.

\section{CONCLUSION}

Judgment creditors attempting to satisfy their judgment from corporate shares owned by the debtor are faced with two problems. First, all corporate stock may not be covered by the provisions of Article 8. This might be favorable to the creditor if he could be certain which stock is and which is not included. On the other hand, if it is found that some stocks are not within the Article 8 definition, there may be no procedure for reaching such stock by legal process under available statutes. If it is the intention of the legislatures to include all corporate stock in Article 8, it might be well to provide explicitly that a "security" is corporate stock and any other instrument which comes within the meaning of the functional test presently found in section 8-102(1). The fact that this was not done, especially in light of the experience with the USTA, gives some weight to the conclusion that all corporate stocks were not intended to be included.

The second problem area is the lack of uniformity in the law 
applicable to shares of stock in businesses incorporated in the United States. The difficulty is created because Delaware has not accepted the provisions of Article 8 on attachment and levy upon securities. The problem is enhanced by the fact that a large number of national corporations are incorporated in Delaware.

This situation leaves several choices. First, the federal government can include this aspect of the regulation of corporate shares in the ever increasing package of securities regulations already existing. Although this seems very logical, it runs contrary to the concept of the local nature of creditors' remedies. New thoughts in the area of creditors' remedies may appear, however, because of recent Supreme Court cases holding that certain state creditors' remedies violate the due process clause of the fourteenth amendment $t^{63}$ and because of the increasing interest in uniform federal exemptions for debtors. ${ }^{64} \mathrm{Sec}-$ ond, other states could persuade Delaware to follow the uniform policy established in the UCC. This is not likely to occur, however, because pressure has already been unsuccessfully exerted through the Commissioners on Uniform State Laws. Third, the corporations which have incorporated in Delaware could be persuaded to reincorporate in other states. This will not happen because the issuing corporation has no direct concern in creditors' problems; consequently, such a decision would have to be made in response to other corporate interests. Finally, judgment creditors can continue to expend time and money in order to levy upon shares that their debtors own in Delaware corporations.

Thus, it appears that the lack of uniformity in the law will remain unless the federal government chooses to regulate the attachment or levy of corporate stock in businesses incorporated in the United States. Whatever the method of regulation, it should provide a swift, uniform, and economical means for creditors to subject this asset to their judgment.

63. See Fuentes v. Shevin, 407 U.S. 67 (1972) (replevin); Sniadach v. Family Fin. Corp. 395 U.S. 337 (1969) (garnishment).

64. See Countryman, supra note 2; Consumer Credit Protection Act, 15 U.S.C. $\S$ 167177 (1970). 
